\title{
Increasing Trend of Rainfall Over Agumbe, Western Ghats, India in the Scenario of Global Warming
}

\author{
B.R. Manjunatha ${ }^{1,{ }^{*}}$, K. Balakrishna ${ }^{2}$, K.N. Krishnakumar ${ }^{3}$, H.V.Manjunatha ${ }^{1}$, K. Avinash ${ }^{4}$, \\ A.C. Mulemane ${ }^{5}$ and K.M. Krishna ${ }^{6}$ \\ ${ }^{I}$ Department of Marine Geology, Mangalore University, Mangalagangothri-574 199, Karnataka India \\ ${ }^{2}$ Department of Civil Engineering, Manipal Institute of Technology, Manipal University, Manipal -576104, India \\ ${ }^{3}$ Department of Geology, University of Kerala, Thruvananthapuram, India \\ ${ }^{4}$ National Centre for Antarctic \& Ocean Research, Headland Sada, Vasco-da-Gama, Goa 403 804, India \\ ${ }^{5}$ Irrigation Department, Office of the Chief Engineer, Shimoga, Karnataka, India \\ ${ }^{6}$ Department of Meteorology \& Oceanography, Andhra University, Visakhapatnam-530003, India
}

\begin{abstract}
There are quite a number of conflicting conclusions about inter-annual trends of the monsoon rainfall over South Asia as a result of global warming. Western Ghats, next to Himalayas are the principal watershed areas for the rivers of India. In this study, an attempt has been made to understand the inter-seasonal and inter-annual patterns rainfall over Agumbe - popularly known as the Cheerapunji of the South India. Since this region is particularly influenced by the south-west monsoon, the monthly rainfall data of this station from 1963 to 2010 have been studied to understand the longterm trend in rainfall as a consequence of global warming. Seasonally, the maximum amount in rainfall occurs during the summer followed by fall, spring and the least during winter $(84.31$ to $98.98 \%, 0$ to $9.92 \%, 0$ to $8.23 \%$ and 0 to $0.41 \%$ respectively). Though the rainfall of the study area is generally in phase with that of all India summer rainfall, however, there is an increasing trend of both inter-annual and seasonal rainfall suggesting the induction of global warming in supplying moisture from the Indian Ocean. The rate of increase has been found to be maximum during the summer, followed by spring and fall seasons with a pronounced increasing in the annual rainfall $(22.85,4.29,2.82$ and 28.58 $\mathrm{mm} / \mathrm{yr}$ respectively). Generally, the annual lows and highs are generally in agreement with El Niño and La Niña years respectively. However, about $80 \%$ of the rainfall data fall within the mean of $7304 \mathrm{~mm}$ and $1087 \mathrm{~mm} 1 \sigma$ standard deviation. Despite increasing in rainfall, the major part of the study area suffers from the shortage of water resource particularly during the spring season. Therefore, this study suggests for a better management of the water resource in high rainfall terrain.
\end{abstract}

Keywords: Agumbe, interannual variability, rainfall, south-western India, tropics, Western Ghats.

\section{INTRODUCTION}

Monsoon rainfall is the most important source of fresh water for hydrological cycle, particularly in the tropics and sub-tropical regions. More than half of the global population depend upon the monsoon rains for drinking water, agriculture, power generation and the whole community economy of the South Asian countries depends on monsoon rains $[1,2]$. The monsoon rain system seems to be perturbed with regional atmospheric anthropogenic activity especially due to biomass burning and combustion of fossil fuels [3-5]. Although the impact of atmospheric pollution is intense within the proximity of industries, however, anthropogenic and anthropocentric activities like urban growth, mining, quarrying, mineral processing and smelting leads to pollution

\footnotetext{
*Address correspondence to this author at the Department of Marine Geology, Mangalore University, Mangalagangothri-574 199, Karnataka India; E-mail omsrbmanju@yahoo.com
}

at regional to global scale [5, 6]. The impact of atmospheric pollutants has been noticed not only on monsoon rains, but also on retreat of mountain glaciers [6, 7]. This has implication on water budget particularly in the densely populated Indo-Gangetic alluvial plains during the spring and summer seasons. Numerous studies indicate that the trend of monsoon rainfall is contrasting under the scenario of global warming [8-12]. In this study an attempt has been made to understand the long-term rainfall trend as an impact of global warming.

The West Coast of India is a narrow strip of land that exists between the eastern Arabian Sea and Western Ghat mountains bordering the Peninsular India. The Western Ghats are the major plateau mountains in the Peninsular India. They form the major watershed area of both east as well as west-flowing rivers of the Peninsular India. The agricultural production, power generation and public water supply depend on the monsoon rainfall. The rainfall is quite 
high along the coast $(>200-400 \mathrm{~cm} / \mathrm{yr})$, however, increases considerably along the neighbouring Western Ghats $(\sim 5000$ $\mathrm{mm} / \mathrm{yr}$ ) as a result of orographic effect $[13,14]$. The main objectives of this study are keen to understand the seasonal and interannual trends in rainfall over Agumbe, which is situated on the peak of the Western Ghats. This site is situated not only in the core of summer monsoon air flow, but also receiving the second highest rainfall in India.

\section{DATA AND METHODOLOGY}

Monthly variations in rainfall monitored around Agumbe (Fig. 1) for the period from 1963 to 2010 have been collected from the District Statistical Department, Shimoga, Karnataka, India. These data have been summed up into seasonal and annual levels and plotted as graphs to understand the long-term trends in the seasonal and inter annual variability of the rainfall. The trend in rainfall estimated from the regression line by lease square fit procedure. In order to understand the factor controlling the rainfall trend, the data have been compared with the records of El Niño and La Niña Years and their intensities. The summer monsoon and annual rainfall data are compared with the June, July as well as August, and annual averages of oceanic Niño Indices (ONI).

\section{RESULTS AND DISCUSSION}

The monthly variations of the rainfall data have been grouped into four seasons: winter (December, January and February), spring (March, April and May), summer (June, July, August and September), and fall (October and November). However, the above demarcation may vary from year to year, for instance, the summer rainfall some times may either advance or delay than the usual beginning June 1, and ends either early or later than September 15. The basic statistics of the seasonal and inter annual variability in rainfall have been given in Table $\mathbf{1}$.

The most striking feature in rainfall is that received

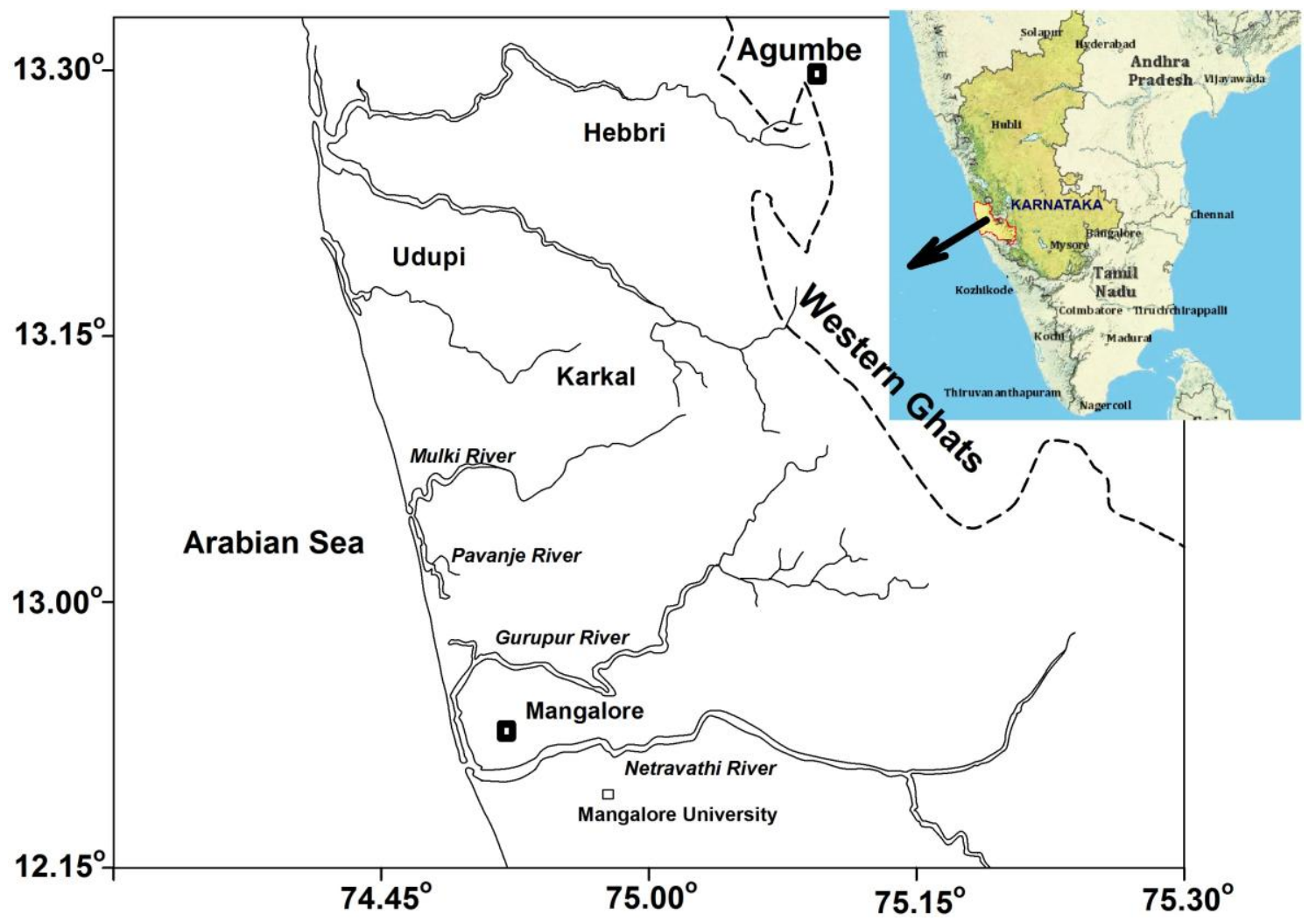

Fig. (1). Map of the study area showing Agumbe along the south-western India.

Table 1. Summary of the basic statistics of rainfall ( $\mathrm{mm} / \mathrm{yr})$ of Agumbe.

\begin{tabular}{|c|c|c|c|c|c|}
\hline & Winter & Spring & Monsoon & Fall & Total rainfall \\
\hline Mean & 1.89 & 192.72 & 6930.13 & 316.93 & 7441.66 \\
\hline SD & 5.68 & 167.09 & 1056.45 & 183.15 & 1143.77 \\
\hline Min & 0.00 & 0.00 & 4853.50 & 0.00 & 5443.10 \\
\hline
\end{tabular}


during the summer that ranges from 4853 to $10455 \mathrm{~mm}$ with an average of $7443 \pm 1144 \mathrm{~mm}$. The average quantum accounts as much as 84 to $99 \%$ with a mean of $93 \pm 3.17 \%$ of the total annual rainfall over the sampling period. The main reason behind the maximum amount in rainfall occurs along the west coast of India is due to orographic effect as a result of the prevalence of long chain of coast parallel Western Ghats (Fig. 1). Immediately after the summer, the rainfall drastically reduces to $317 \mathrm{~mm} \pm 183 \mathrm{~mm}$ during the fall, least of $1.89 \mathrm{~mm} \pm 5.68 \mathrm{~mm}$ during the winter. Whereas, the rainfall tends to begin during the spring $(193 \pm 167 \mathrm{~mm})$ and intensifies during the summer.

The quantum of rainfall, therefore, considerably low during rest of the year that can be arranged in the decreasing order as fall, spring and winter respectively $(4.23 \pm 2.36 \%$, $2.53 \pm 2.09 \%$ and $0.03 \pm 0.08 \%)$. The quantity of rainfall received during the winter has been negligible. This can be explained by the dominance of wind flow from central Asia through north-eastern India to the area of investigation. The seasonal or semi-annual reversal wind pattern from southwest to north-east [15] results in the variations in the moisture transport as the airmass that originates from the north-east part of India and South Asia is generally dry and cold during the winter as compared to warm and moist air that advects over the northern Indian Ocean as well as Arabian Sea, during the summer.

Correlation coefficients have been computed to understand the extent of relationship among the seasonal variability in the rainfall. The most significant and highest correlation is between the summer and annual rainfall $(\mathrm{r}=$ 0.90 at $99 \%$ confidence level). As explained earlier, the winter rainfall is not correlated significantly with monsoon and remaining other seasons (Table 2). Nevertheless, the rainfall during the fall and spring seems to be dependent and these two in turn correlated significantly with the summer rainfall, suggesting the importance of the moisture transport from the winds advecting over the Arabian Sea and the Northern Indian Ocean. With the exception of winter rainfall, all seasonal rainfall tends to increasing with time, implying the importance of the global warming in mobilizing the moisture. The rate of increase in rainfall estimated from the least square fit lines (Fig. 2) found to be maximum for the annual rainfall, followed by summer, fall and spring $(28.58 \mathrm{~mm} / \mathrm{yr}, 22.85 \mathrm{~mm} / \mathrm{yr}, 4.29 \mathrm{~mm} / \mathrm{yr}$, and $2.82 \mathrm{~mm} / \mathrm{yr}$ respectively). These trends indeed almost coherent with the correlation coefficient between time in terms of years lapsed with rainfall.

In order to understand the factor controlling the longterm variability in the rainfall, seasonal and annual rainfall of the Agumbe region have been plotted as Fig. (3) along with a bar of standard deviation in the rainfall. Also plotted in the Fig. (2) are Oceanic Niño Indices (ONI) which are used to understand the teleconnection of rainfall over the Agumbe with El Niño (warm)/ La Niña (cool) years over the tropical Pacific (cited February 24; 2014; http://ggweather.com/enso/ oni.htm). The annual rainfall over Agumbe ranges from 5443 $\mathrm{mm}$ to $11127 \mathrm{~mm}$ with a mean of $7304 \mathrm{~mm}$ and standard deviation of $1087 \mathrm{~mm}$. About $80 \%$ of the interannual rainfall data points scattered within the one standard deviation of the mean suggests the consistency of the monsoon. Moreover, approximately $10 \%$ each of the observations fall above and below the standard deviation, implying near normal distributions of the rainfall data. The lowest rainfall recorded over the years from 1963 to 2010 was during 1987 and highest was during $1994(5443 \mathrm{~mm}$ and $11127 \mathrm{~mm}$ respectively). Surprisingly, both the former and latter belongs to the moderate El Niño year. However, some of low rainfall years of Agumbe (lower than one sigma standard deviation) belong to moderate to strong El Niño years (1987, 1967 and 1972 respectively). Similarly, almost none of high rainfall years (above the $1 \sigma$ standard deviation) of Agumbe belong to La Niña years. The summer and annual rainfall of Agumbe plotted against the June, July and August and annual average ONI (Fig. 4). Although there is a decreasing trend of the annual rainfall, however, there is quite dramatic decreasing trend noticed for the rains during summer. Despite statistically insignificance, all these observations suggest that the rainfall trend over Agumbe seems to be inversely related to temperature changes over the east tropical Pacific Ocean.

Numerous studies indicate that the trend of monsoon rainfall is either increasing under the scenario of global warming [8,9,11-16] or decreasing trend [10, 17-19] Naidu et al. [20] have analysed seasonal and interannual variations in the rainfall over 30 meteorological subdivisions of India spanning a long-time span of 1871 to 2005 . They found a general tendency of increasing in rainfall $(13.3 \mathrm{~mm} /$ decade $)$, with a decreasing trend from 1916 to 1930 . Since the data used in this paper are from the early 1960s, the dry episodes have not been noticed thereafter. Sinha Ray and Srivastava [21] have shown that there are both increasing and decreasing trends in rainfall noticed over India, particularly

Table 2. Inter parametric correlations of seasonal and annual rainfall (numbers in bold are significant at the 0.01 level).

\begin{tabular}{|c|c|c|c|c|c|c|}
\hline & Year & Annual & Winter & Spring & Monsoon & \\
\hline \hline Year & 1.00 & & & & \\
\hline Annual & 0.41 & 1.00 & & & \\
\hline Winter & 0.22 & 0.07 & 1.00 & & \\
\hline Spring & 0.34 & 0.33 & -0.08 & 1.00 & \\
\hline Monsoon & 0.33 & 0.90 & 0.11 & 0.39 & 1.00 & 0.51 \\
\hline Fall & 0.27 & 0.35 & 0.08 & 0.25 & 1.00 \\
\hline
\end{tabular}



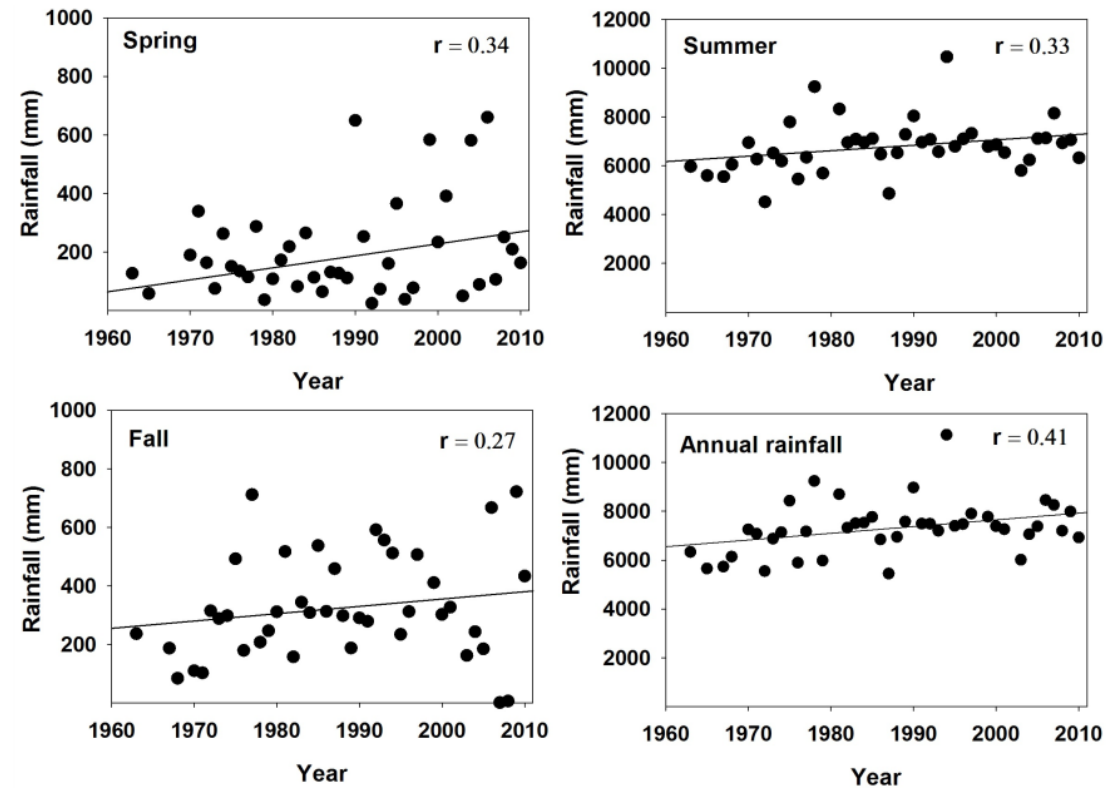

Fig. (2). Seasonal and inter-annual variability in the rainfall trends of Agumbe.

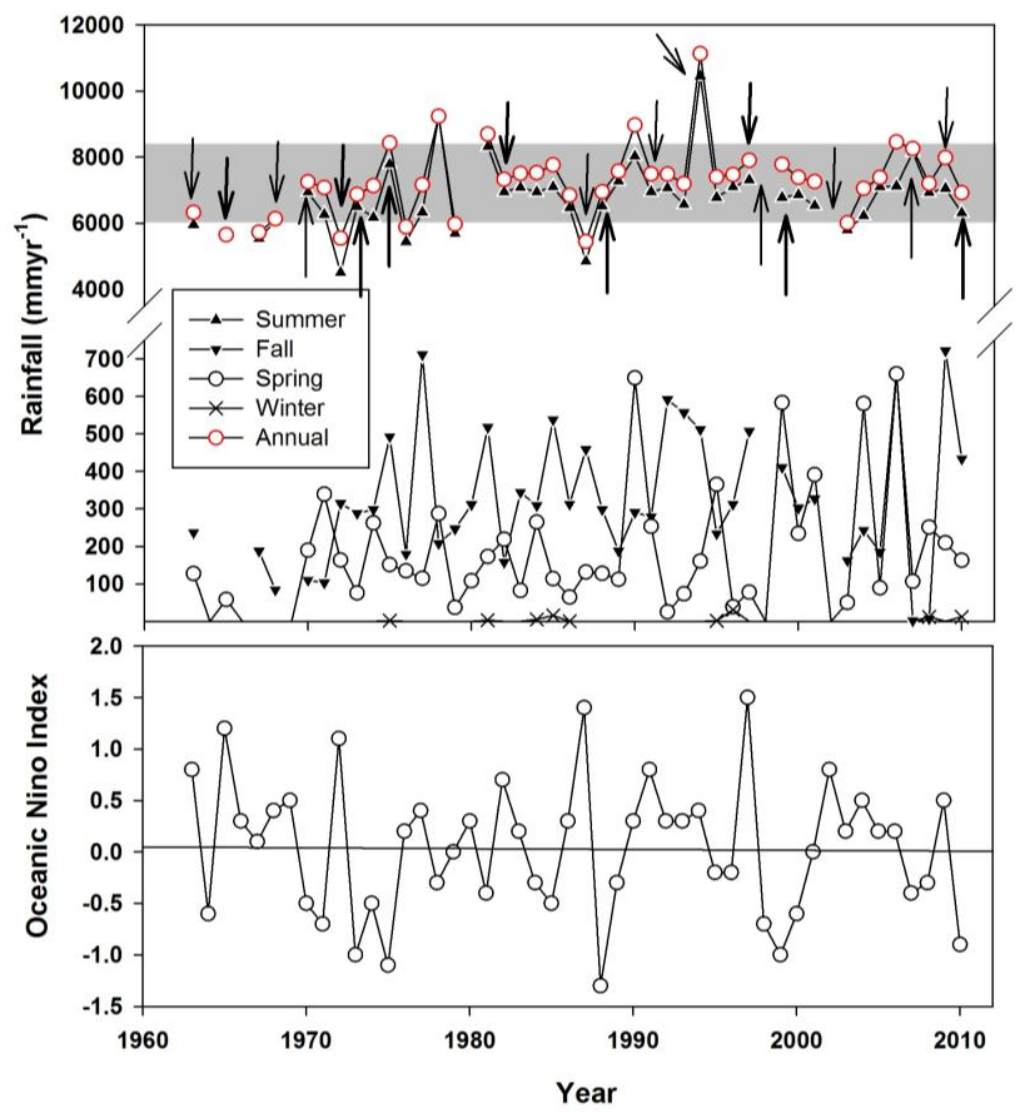

Fig. (3). Seasonal and inter-annual variability of rainfall over Agumbe. The horizontal grey row represents the average rainfall along with $1 \sigma$ standard deviation. Up and down arrows are El Niño La Niña years respectively. The thickness of arrows indicates moderate to strong intensities.

during the summer monsoon, however, decreasing trend quite consistent during remaining seasons. The reason explained for the decrease of rainfall over India is related to sea surface temperature and the weakening of tropical easterly jet (TEJ) $[18,22]$. The insignificant relationship of
Agumbe rainfall with the ONI is similar to what has been reported for the Indian monsoon [23].

Therefore, it is apparent that the both trends of rainfall are evident over the Indian sub-continent. The inter-annual trends in rainfall observed over Agumbe appears to be good 


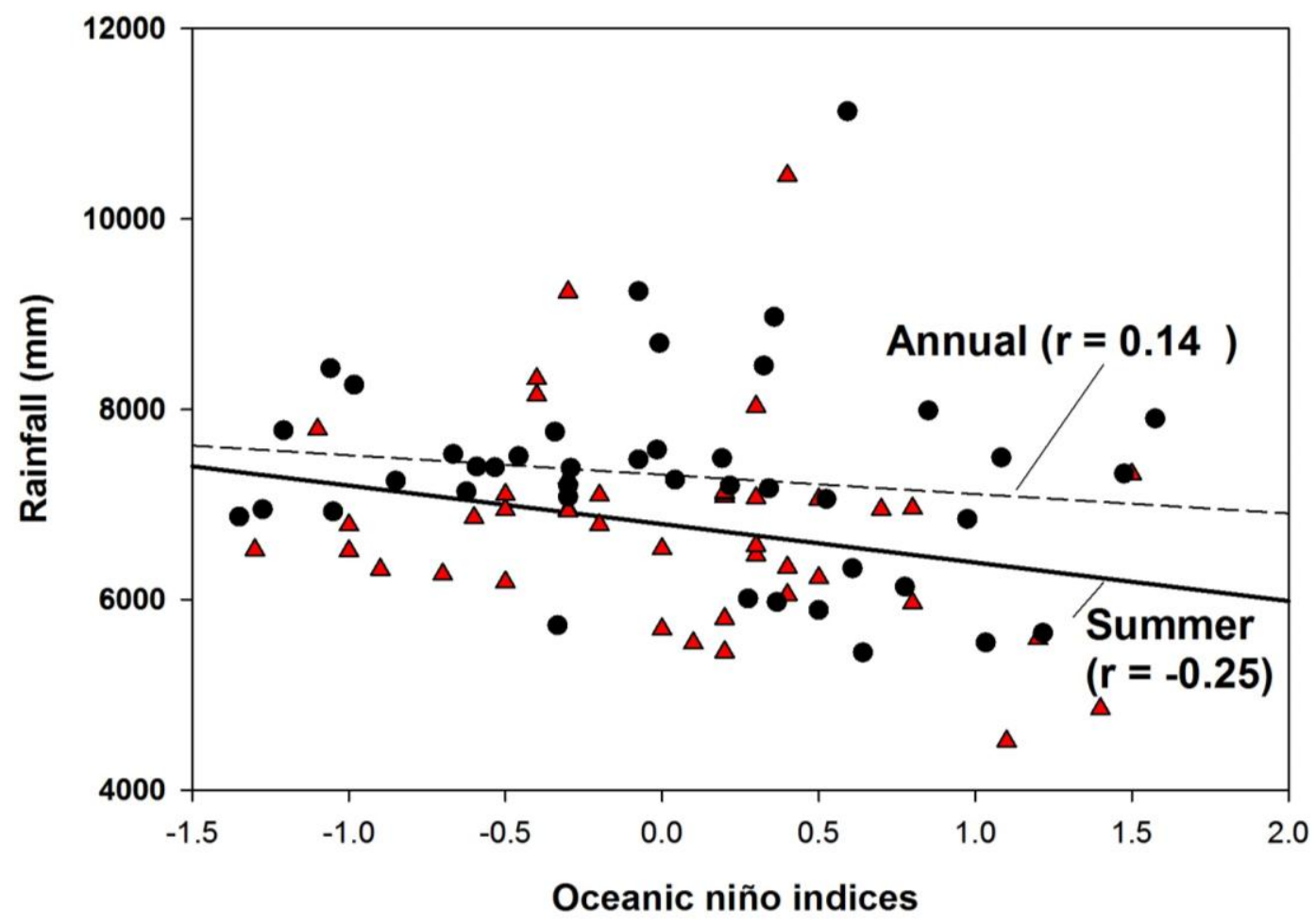

Fig. (4). Relationship between the annual rainfall and annual oceanic Niño indices, and summer rainfall and summer monsoon (June, July and August) indices.

news, however, the rainfall pattern seems to be episodic, i.e., intense rainfall events occur in short time due to variations in tropical convergence zone (TCZ) with low out-going longwave radiation (OLR) over a large-scale zonal belt, offshore convective system, midtropospheric cyclone (MTC) and offshore vortex [14].

Further analysis of data through sector-wise may provide better information. Since the major part $(93 \pm 3.20 \%)$ of the annual rainfall occurs during the summer season- that begins during June and ends up during September, with a prolonged gap of eight months in a year, water scarcity has being noticed in the vicinity around the area of investigation. Hence, there is a need to increase the water management activities for agriculture and domestic purposes.

\section{CONCLUSION}

The long-term variations in rainfall over Agumbe from 1963 to 2010 show an enhancing trend in the increasing order of importance from spring, fall, summer and annual (2.82 mm/yr, $4.29 \mathrm{~mm} / \mathrm{yr}, 22.85 \mathrm{~mm} / \mathrm{yr}$ and $28.58 \mathrm{~mm} / \mathrm{yr}$ respectively). In contrast, the rainfall found to be negligible during the winter $(0.03 \%)$ because of the dry and cold airmass arriving from the north-east. The summer rainfall contributes to about $90 \%$ of the annual, followed by fall and spring due to the warm and moist south-westerly flow of airmass from the Indian Ocean. The increasing pattern implies the impact of global warming which is significant particularly since $1960 \mathrm{~s}$. However, there seems to be an inverse relationship between Oceanic Niño Indices (ONI) of the tropical Pacific Ocean and summer rainfall over Agumbe.

\section{CONFLICT OF INTEREST}

The authors confirm that this article content has no conflict of interest.

\section{ACKNOWLEDGEMENTS}

We thank the District Statistical Department, Shimoga, Karnataka, India for providing monthly rainfall data. We also thank an anonymous reviewer for his constructive comments to improve the quality of the paper. This work is a part of the SIBER project funded by the Ministry of Earth Sciences, Government of India sanctioned to one of us (BRM). Another author (KB) thanks the Dr TMA Pai Endowment Chair in Earth Sciences, Manipal University for technical support.

\section{REFERENCES}

[1] Gadgil S, Abrol YP, Rao PRS. On growth and fluctuation of Indian foodgrain production. Curr Sci 1999; 76: 548-56.

[2] Gadgil S, Kumar KR. Agriculture and economy. Wang B, Ed. The Asian Monsoon: Springer-Verlag 2006; pp. 203-257.

[3] Duce RA, Liss PS, Merrill JT, et al. The atmospheric input of trace species to the world ocean. Global Biogeochem Cycles 1991; 5: 193-259.

[4] Ramanathan V, Agrawal M, Akimoto H, et al. Atmospheric Brown Clouds: Regional Assessment Report with Focus on Asia. Published by the United Nations Environment Program: Nairobi, Kenya 2008; 1-360.

[5] Andreae MO, Ramanathan V. Climate's dark forcings. Science 2013; 340: 280-281.

[6] Crutzen PJ, Ramanathan V. Atmospheric chemistry and climate in the anthropocene: where are we heading? Earth System Analysis for Sustainability, Cambridge. MA: MIT Press 2003: pp. 265-292.

[7] Bolch T, Kulkarni A, Kääb A, et al, The state and fate of Himalayan Glaciers. Science 2012; 336: 310-4. 
[8] Goswami BN, Venugopal V, Sengupta D, et al. Increasing trend of extreme rain events over India in a warming environment. Science 2006; 314: 1442-1444.

[9] Rajeevan MJ, Bhate J, Jaswal AK. Analysis of variability and trends of extreme rainfall events over India using 104 years of gridded daily rainfall data. Geophys Res Lett 2008; 35: L18707, doi:10.1029/2008GL035143

[10] Kumar V, Jain SK, Singh Y. Analysis of long-term rainfall trends in India. Hydrol Sci J 2010; 55: 484-496.

[11] Kitoh A, Endo H, Kumar KK, et al. Monsoons in a changing world: a regional perspective in a global context. J Geophys Res 2013; doi:10.1002/jgrd.50258

[12] Prakash S, Sathiyamoorthy V, Mahesh C, et al. Is summer monsoon rainfall over the west coast of India decreasing? Atmosph Sci Lett 2013; 14: 160-163. doi: 10.1002/as12.433

[13] Dikshit KR. Anomalies in the distribution of rainfall on the west coast of India. Indian Geograp J 1979; 54: 1-13.Francis PA, Gadgil $\mathrm{S}$, Intense rainfall events over the west coast of India. Meteorol Atmos Phys 2006; 94: 27-42, doi 10.1007/s00703-005-0167-2

[14] Cadet DL, Diehl BC. Inter-annual variability of surface fields over the Indian Ocean in recent decades. Monthly Weather Review 1984: 112: 1921-1935.

[15] Gautam R, Hsu NC, Lau K-M, et al. Aerosol and rainfall variability over the Indian monsoon region: distributions, trends and coupling, Ann Geophys 2009; 27: 3691-3703, doi:10.5194.
[16] Joseph PV, Simon A. Weakening trend of the southwest monsoon current through peninsular India from 1950 to the present. Curr Sci 2005; 89: 687-694.

[17] Kumar RMR, Krishnan R, Sankar S, et al. Increasing trend of "break-monsoon" conditions over India - role of ocean-atmosphere processes in the Indian Ocean. IEEE Geosci. Remote Sensing Lett 2009; 6: 332-336.

[18] Prakash S, Sathiyamoorthy V, Mahesh C, et al. Is summer monsoon rainfall over the west coast of India decreasing? Atmosph Sci Lett 2013; 14: 160-163. doi: 10.1002/asl2.433

[19] Naidu CV, Durgalakshmi K, Muni Krishna K. et al. Is summer monsoon rainfall decreasing over India in the global warming era? J Geophys Res 2009; 114, D24108, doi:10.1029/2008JD011288

[20] Ray SKC, Srivastava AK. Is there any change in extreme events like droughts and heavy rainfall? In: INTROPMET-97 (IIT New Delhi, 2-5 December 1997).

[21] Sathiyamoorthy V. Large scale reduction in the size of the tropical easterly Jet. Geophys Res Lett 2005: 32, L14802, doi: 10.1029/2005GL022956

[22] Kumar KK, Rajagopalan B, Cane MA. On the weakening relationship between the Indian monsoon and ENSO. Science 1999; 284: 2156-9.

Received: July 23, 2014

Revised: August 07, 2014

Accepted: August 08, 2014

(C) Manjunatha et al.; Licensee Bentham Open.

This is an open access article licensed under the terms of the Creative Commons Attribution Non-Commercial License (http://creativecommons.org/licenses/by-nc/3.0/) which permits unrestricted, non-commercial use, distribution and reproduction in any medium, provided the work is properly cited. 